\title{
Estimation of Bed-Material Transport in the lower Chetco River, Oregon, Water Years 2009-2010
}

By J. Rose Wallick and Jim E. O'Connor

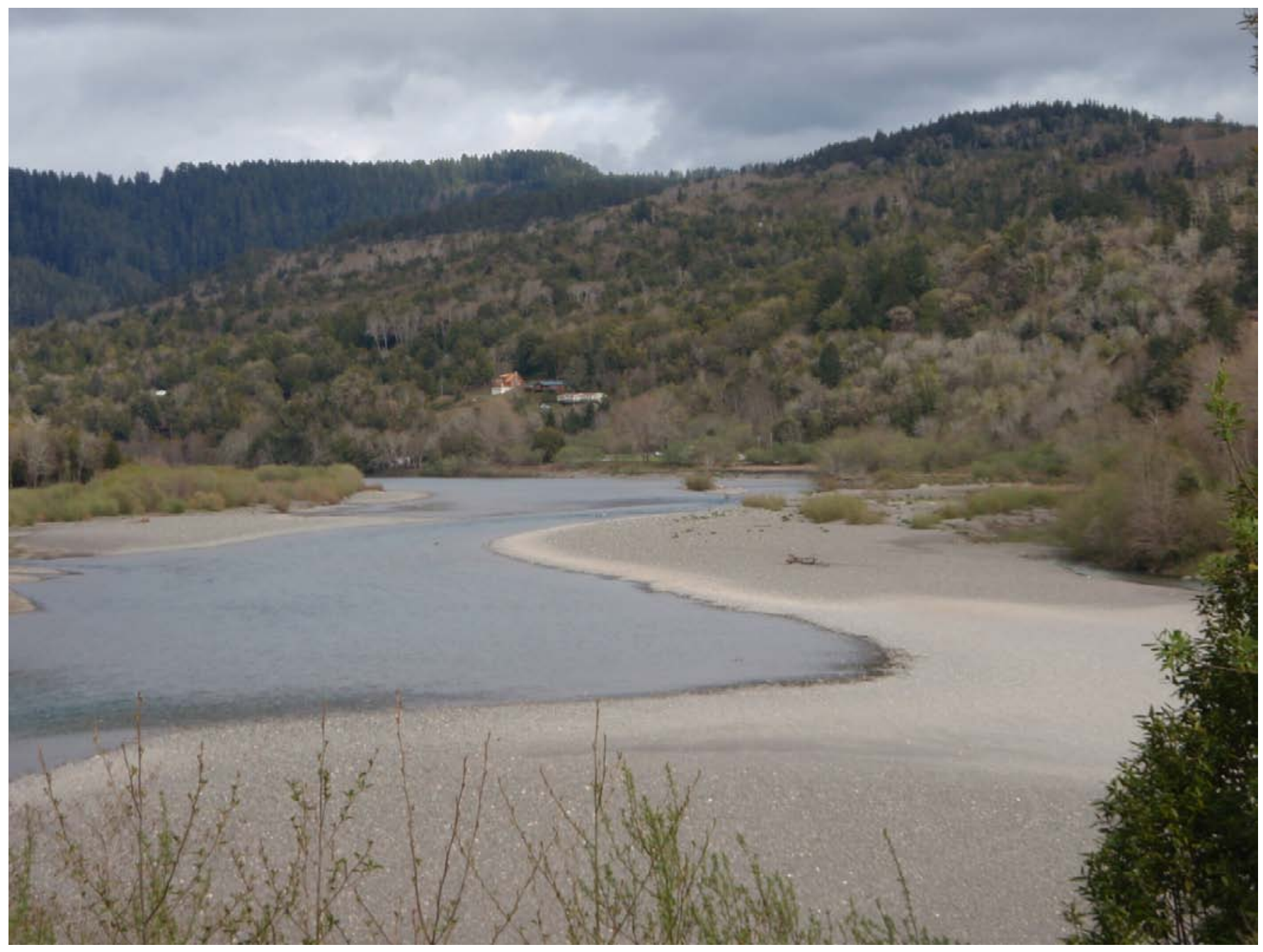

Prepared in cooperation with the U.S. Army Corps of Engineers and the Oregon Department of State Lands

Open-File Report 2011-1123

U.S. Department of the Interior

U.S. Geological Survey 
Cover: The Chetco River near its confluence with the North Fork Chetco River, looking upstream. Gravel bars line the stream on both banks. (Photograph by J. Rose Wallick, U.S. Geological Survey, April 9, 2008.) 


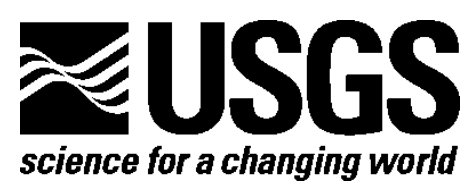

Prepared in cooperation with the U.S. Army Corps of Engineers and the Oregon Department of State Lands

\section{Estimation of Bed-Material Transport in the lower Chetco River, Oregon, Water Years 2009-2010}

By J. Rose Wallick and Jim E. O'Connor

Open-File Report 2011-1123

U.S. Department of the Interior

U.S. Geological Survey 


\section{U.S. Department of the Interior \\ KEN SALAZAR, Secretary}

\section{U.S. Geological Survey \\ Marcia K. McNutt, Director}

U.S. Geological Survey, Reston, Virginia 2011

For product and ordering information:

World Wide Web: http://www.usgs.gov/pubprod

Telephone: 1-888-ASK-USGS

For more information on the USGS-the Federal source for science about the Earth, its natural and living resources, natural hazards, and the environment:

World Wide Web: http://www.usgs.gov

Telephone: 1-888-ASK-USGS

Suggested citation:

Wallick, J.R., and O'Connor, J.E., 2011, Estimation of bed-material transport in the lower Chetco River, Oregon, water years 2009-2010: U.S. Geological Survey Open-File Report 2011-1123, 12 p.

Any use of trade, product, or firm names is for descriptive purposes only and does not imply endorsement by the U.S. Government.

Although this report is in the public domain, permission must be secured from the individual copyright owners to reproduce any copyrighted material contained within this report. 


\section{Contents}

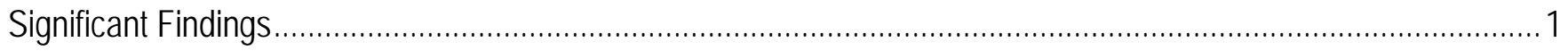

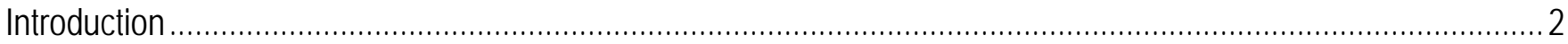

Purpose and Scope

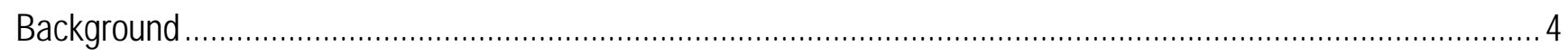

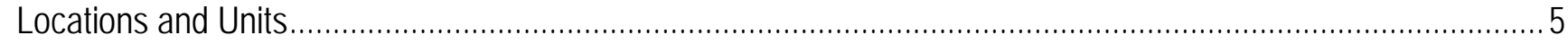

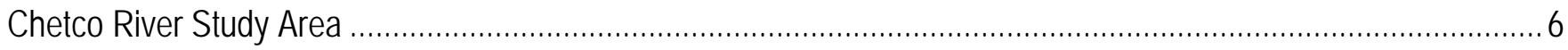

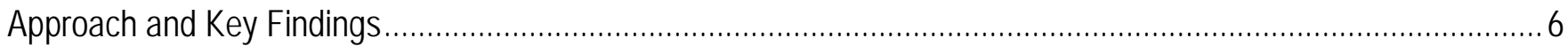

Estimation of Bed-Material Transport Rates Using Established Transport Equations ....................................... 6

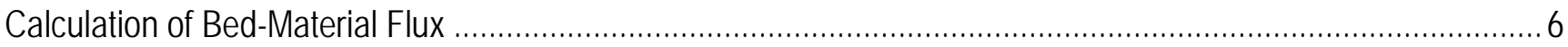

Results of Calculated Bed-Material Flux ....................................................................................

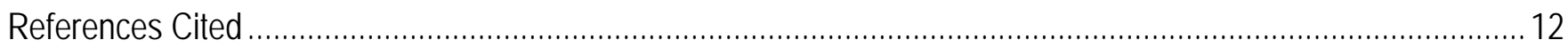

\section{Figures}

Figure 1. Map showing drainage basin and study area, Chetco River, Oregon.

3

Figure 2. Orthophotograph showing an example of an alternating bar sequence near flood-plain kilometer (FPkm) 11, Chetco River Oregon.

4

Figure 3. Graphs showing discharge and calculated bed-material transport capacity for water years 2009-2010 at the USGS streamflow gaging station at flood plain-kilometer 15.3 (144000000), Chetco River, Oregon.....................8

Figure 4. Graphs showing peak discharge, annual transport capacity, and mean annual discharge for water years 1970-2010 at the USGS streamflow gaging station at flood plain kilometer 15.3 (14400000),

Chetco River Oregon

\section{Tables}

Table 1. Summary of calculated transport capacity, peak flow, and mean annual flow in the Chetco River, Oregon for water years 1970-2010 


\section{Conversion Factors}

\begin{tabular}{|c|c|c|}
\hline Multiply & By & To obtain \\
\hline \multicolumn{3}{|c|}{ Length } \\
\hline centimeter (cm) & 0.3937 & inch (in.) \\
\hline millimeter (mm) & 0.03937 & inch (in.) \\
\hline meter (m) & 3.281 & foot $(\mathrm{ft})$ \\
\hline kilometer (km) & 0.6214 & mile (mi) \\
\hline \multicolumn{3}{|c|}{ Area } \\
\hline square meter $\left(\mathrm{m}^{2}\right)$ & 10.76 & square foot $\left(\mathrm{ft}^{2}\right)$ \\
\hline square kilometer $\left(\mathrm{km}^{2}\right)$ & 0.3861 & square mile $\left(\mathrm{mi}^{2}\right)$ \\
\hline \multicolumn{3}{|c|}{ Volume } \\
\hline cubic meter $\left(\mathrm{m}^{3}\right)$ & 0.0008107 & acre-foot (acre-ft) \\
\hline cubic meter $\left(\mathrm{m}^{3}\right)$ & 35.31 & cubic foot $\left(\mathrm{ft}^{3}\right)$ \\
\hline cubic meter $\left(\mathrm{m}^{3}\right)$ & 1.308 & cubic yard $\left(\mathrm{yd}^{3}\right)$ \\
\hline liter (L) & 0.03531 & cubic foot $\left(\mathrm{ft}^{3}\right)$ \\
\hline \multicolumn{3}{|c|}{ Flow rate } \\
\hline cubic meter per second $\left(\mathrm{m}^{3} / \mathrm{s}\right)$ & 35.31 & cubic foot per second $\left(\mathrm{ft}^{3} / \mathrm{s}\right)$ \\
\hline cubic meter per year $\left(\mathrm{m}^{3} / \mathrm{yr}\right)$ & 1.308 & cubic yard per year $\left(\mathrm{yd}^{3} / \mathrm{yr}\right)$ \\
\hline meter per second $(\mathrm{m} / \mathrm{s})$ & 3.281 & foot per second (ft/s) \\
\hline meter per year (m/yr) & 3.281 & foot per year (ft/yr) \\
\hline millimeter per year (mm/yr) & 0.0397 & inch per year (in/yr) \\
\hline $\begin{array}{l}\text { kilogram per meter per second } \\
{[(\mathrm{kg} / \mathrm{m}) / \mathrm{s}]}\end{array}$ & 4.486 & $\begin{array}{l}\text { pound avoirdupois per foot per } \\
\text { second }[(\mathrm{lb} / \mathrm{ft}) / \mathrm{s}]\end{array}$ \\
\hline \multicolumn{3}{|c|}{ Mass } \\
\hline kilogram (kg) & 2.205 & pound avoirdupois (lb) \\
\hline metric ton (also megagram) & 1.102 & ton (U.S.) \\
\hline
\end{tabular}

\section{Datums}

Vertical coordinate information is referenced to the North American Vertical Datum of 1988 (NAVD 88). Horizontal coordinate information is referenced to the North American Datum of 1983 (NAD 83).

Eevation, as used in this report, refers to the distance above the vertical datum. 


$\begin{array}{ll}\text { Abbreviations and Acronyms } \\ \text { BAGS } & \text { Bedload Assessment in Gravel-bedded Streams } \\ \text { BLM } & \text { Bureau of Land Management } \\ \text { FPkm } & \text { flood-plain kilometer } \\ \text { GIS } & \text { geographic information system } \\ \text { GPS } & \text { global positioning system } \\ \text { HEC-RAS } & \text { Hydrologic Engineering Center's River Analysis System } \\ \text { ka } & \text { kiloannum, a unit of time equal to 1,000 years } \\ \text { LIDAR } & \text { Light Detection and Ranging } \\ \text { MLLW } & \text { mean lower low water } \\ \text { NAIP } & \text { National Agriculture Imagery Program } \\ \text { Rkm } & \text { river kilometer } \\ \text { RMSE } & \text { root mean square error } \\ \text { RTK } & \text { real-time kinematic } \\ \text { USFS } & \text { U.S. Forest Service } \\ \text { USGS } & \text { U.S. Geological Survey } \\ \text { UTM } & \text { Universal Transverse Mercator } \\ \text { WY } & \text { water year }\end{array}$


This page is intentionally blank 


\title{
Estimation of Bed-Material Transport in the lower Chetco River, Oregon, Water Years 2009-2010
}

\author{
By J. Rose Wallick and Jim E. O'Connor
}

\section{Significant Findings}

This assessment of bed-material transport uses methods developed in a previous study (Wallick and others, 2010) to estimate bedmaterial flux at the USGS Chetco River streamflow gaging station located at flood-plain kilometer 15 (14400000). On the basis of regressions between daily mean flow and transport capacity, daily bed-material flux was calculated for the period October 1, 2008 to March 30, 2011. The daily flux estimates were then aggregated by water year (WY) for WY 2009 and WY 2010 and the period April 1March 31 during 2008-09, 2009-10 and 201011. The main findings were:

- $\quad$ Estimated bed-material flux for WY 2009 (October 1, 2008 to September 30, 2009) was 87,300 metric tons as calculated by the Parker (1990a, b) equation (hereinafter "the Parker equation”) and 116,900 metric tons as calculated by the Wilcock and Crowe (2003) equation (hereinafter "the WilcockCrowe equation”).

- Estimated bed-material flux for water year 2010 (October 1, 2008 to September 30, 2009) was 56,800 metric tons as calculated by the Parker equation and 96,700 metric tons as calculated by the Wilcock-Crowe equation.

- Estimated bed-material flux for April 1, 2008, to March 31, 2009, was 84,700 metric tons as calculated by the Parker equation and 111,700 metric tons as calculated by the Wilcock-Crowe equation. Flux values from
April 1 to September 30, 2008, are from Wallick and others (2010).

- $\quad$ Estimated bed-material flux for April 1, 2009, to March 31, 2010, was 45,500 metric tons as calculated by the Parker equation and 79,100 metric tons as calculated by the Wilcock-Crowe equation.

- Estimated bed-material flux for April 1, 2010, to March 31, 2011, was 67,100 metric tons as calculated by the Parker equation and 134,300 metric tons as calculated by the Wilcock-Crowe equation. These calculations used provisional flow data for December 29, 2010, to March 31, 2011, and may be subject to revision.

- Water years 2009 and 2010 both had less bed-material transport than the average annual transport values of 105,300 and 152,300 metric tons for the period 19702010 as calculated by the Parker and Wilcock-Crowe equations, respectively. 


\section{Introduction}

The Chetco River is a steep, gravel-bed river in southwestern Oregon that drains 914 $\mathrm{km}^{2}$ of the rugged Klamath Mountains before entering the Pacific Ocean $5 \mathrm{~km}$ north of the California-Oregon State line (fig. 1). Downstream of the confluence of the South Fork Chetco River at river kilometer (Rkm) 29, the Chetco River is flanked by varying widths and areas of gravel bars and flood plains. Downstream of Rkm 18, the channel is fully alluvial and characterized by expansive gravel bars whose positions are constrained by valley geometry (fig. 2 [p. 4]). Several of these voluminous gravel bars have been mined as a source of aggregate for the last several decades. Ongoing permitting actions have given rise to questions of possible effects from such mining on physical channel conditions (for example, Kondolf, 1994, 1997), prompting the U.S. Army Corps of Engineers, in conjunction with regulatory agencies and stakeholder groups, to request that the U.S. Geological Survey (USGS) complete a measurement and analysis program to evaluate transport rates of bed material and to assess changes in channels and flood plains for the lower $18 \mathrm{~km}$ of the Chetco River. In 2010, the USGS completed a comprehensive study of channel change and bed-material transport in the lower Chetco River for WY 1970-2008 (Wallick and others, 2010). This study uses identical methods to calculate bed-material flux for WY 2009 and 2010.

\section{Purpose and Scope}

This report presents daily bed-material transport as calculated at the location of the USGS Chetco River streamflow gaging station for October 1, 2008, to March 30, 2011. The daily flux estimates were calculated using equations of bedload flux described in Wallick and others (2010) and aggregated by water year beginning October 1 and extending through September 30 for WY 2009 and 2010. The daily flux estimates also were summed to determine annual totals for April 1-March 31 for 2008-09, 2009-10, and 2010-11. Together with the longterm estimates of bed-material recruitment provided in Wallick and others (2010), the transport values in this report enable estimation of bedload flux for the 40-year period 19702010 and enhance overall understanding of annual variation in bed-material flux in the lower Chetco River.

Refer to Wallick and others (2010) for a description of the study area (including basin geology, hydrology, landuse, and historical disturbances to the channel, such as instream gravel mining) and data types and methods used to analyze channel change and bed-material transport in this study. 


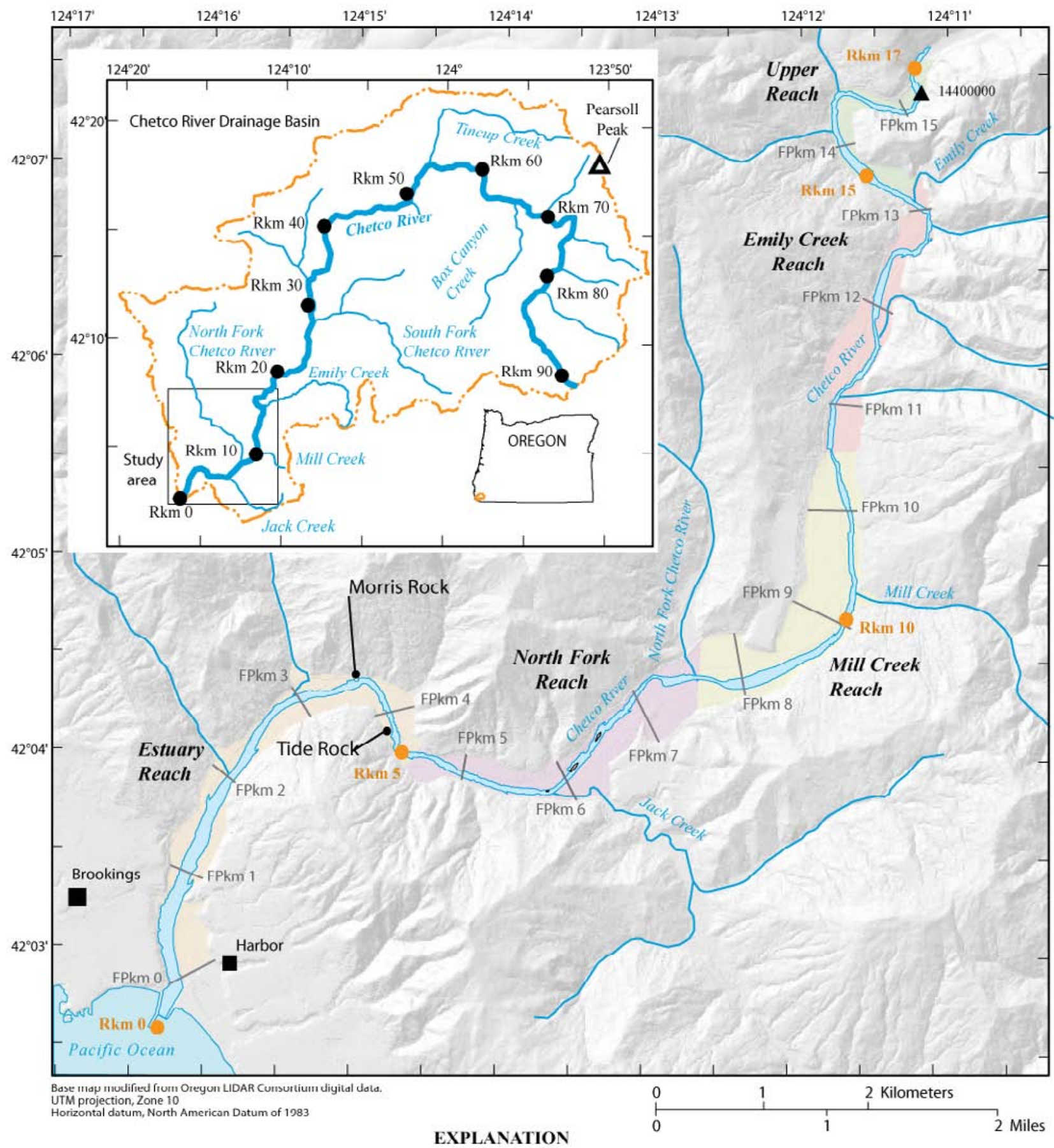

A USGS streamflow gaging station

Rkm $5 \bigcirc$ River kilometer

FPkm 1 Flood-plain kilometer

Figure 1. Map showing drainage basin and study area, Chetco River, Oregon. The reaches analyzed were defined by valley geomorphology and tributary junctions. Morris Rock and Tide Rock are informal names for prominent local landmarks. Topography based on U.S. Geological Survey 10-m digital elevation data and Light Detection and Ranging (LIDAR) topography acquired in 2008. 


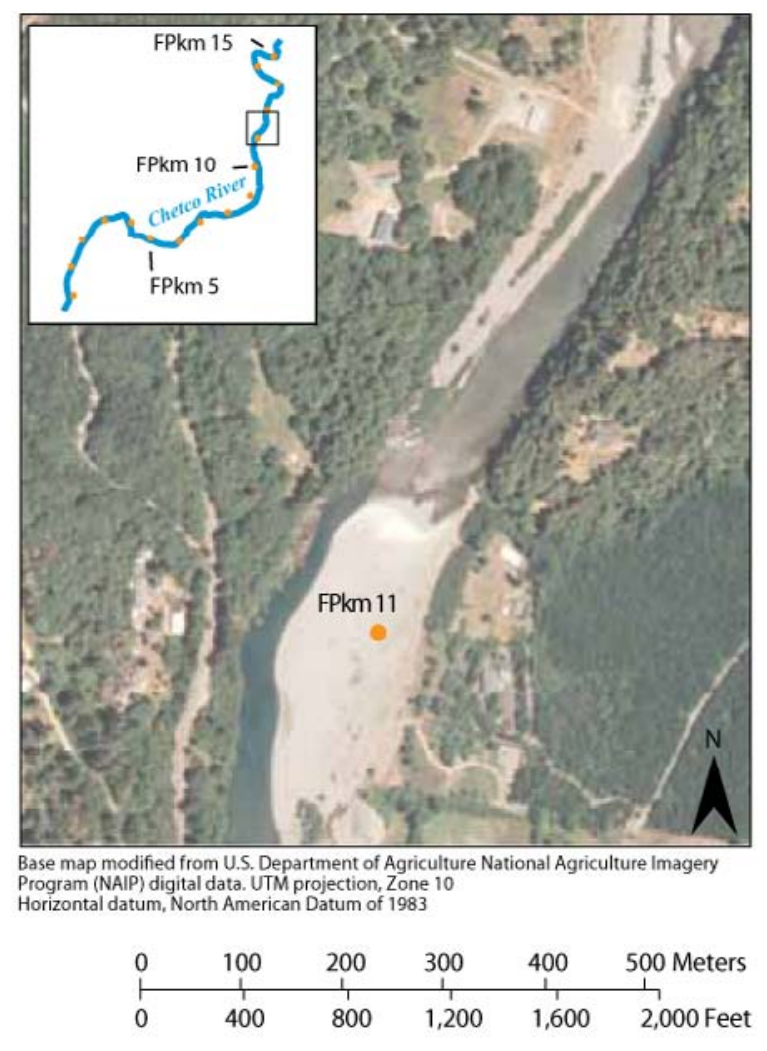

EXPLANATION

FPkm 11 Flood-plain kilometer

Figure 2. Orthophotograph showing an example of an alternating bar sequence near flood-plain kilometer (FPkm) 11, Chetco River Oregon. The photograph, from 2005, depicts large, channelflanking gravel bars and the low-flow channel. Flow is to the south.

\section{Background}

In Oregon, rivers potentially subject to inchannel gravel extraction undergo a two-phase process of review and assessment by multiple regulatory agencies, such as the U.S. Army Corps of Engineers. The first phase is a preliminary assessment of "vertical stability" primarily based on available information. If the Phase I analysis shows no clear evidence of adverse channel or flood plain conditions, a Phase II analysis may be initiated to provide more information relevant to permitting decisions. For the Chetco River, a Phase I analysis was completed in May 2007 (Janine Castro, U.S. Fish and Wildlife Service, written commun., 2007). This assessment of maps and surveys concluded that although the lowermost $2 \mathrm{~km}$ of the river "appears to have deepened slightly over the past 20 years," there was no evidence of systematic channel incision for the balance of the lower $18 \mathrm{~km}$ of the Chetco River. These findings prompted the U.S. Army Corps of Engineers to request that the USGS complete a more extensive, Phase II, analysis for the Chetco River. The Phase II analysis, completed by Wallick and others (2010), consisted of data acquisition and analysis aimed at (1) determining spatial and temporal rates of bedmaterial transport and

(2) assessing planform and vertical changes to the river channel. Specific tasks in the Phase II analysis included:

1. Detailed analysis of historical channel change from 1939 through 2008

2. Direct measurements of bedload flux in the winter of 2008-09

3. Estimation of annual bed-material transport for 1970-2008 using equations of bedload flux

4. Estimation of bed-material transport for 1995-2008 from changes in channel morphology

5. Comparison of Chetco River bedmaterial flux rates with those in nearby basins.

Among the findings from these multiple, independent analyses, Wallick and others (2010) determined that bed-material flux in the lower $18 \mathrm{~km}$ of the Chetco River was transport limited-that is, the transport capacity (the amount of sediment the channel could, theoretically, transport given its geomorphic and hydrologic characteristics) was approximately balanced by sediment supply. Average annual bed-material flux for the period 1970-2008 was 
approximately 84,000-210,000 metric tons. Most of this sediment was routed through the historically stable upper study reaches and deposited in the more dynamic lower gradient reaches. Analyses of channel change found a large reduction in bar area from 1939 to 2005 in the lower $18 \mathrm{~km}$ of the channel and up to $2 \mathrm{~m}$ of incision for large parts of the study area, which were attributed to a combination of (1) bedsediment removal and (2) transient effects as the river adjusted to large volumes of sediment delivered by the flood of December 1964 .

On the basis of these findings, the U.S. Army Corps of Engineers and other regulatory agencies are working to adaptively manage instream gravel extraction in the Chetco River. Under currently proposed guidelines, the USGS will provide annual estimates of gravel recruitment, which regulatory agencies will use to determine the level of permissible gravel extraction. An ongoing monitoring and analysis program also entails additional measurements of bed-material transport to improve the existing transport capacity relations and ultimately establish a sediment-discharge rating curve for the Chetco River. Although two bedload transport measurements were obtained in the winter of 2010-2011, the findings from these measurements will be summarized in a subsequent report and are not reported herein. Future monitoring efforts will likely also incorporate future channel mapping from LIDAR and bathymetric surveys to assess longterm changes to channel morphology.

\section{Location References}

Locations along the channel alignment in summer 2008 are referenced to river kilometers $(\mathrm{Rkm})$ measured from the mouth of the Chetco River (fig. 1) along the channel centerline mapped from Light Detection and Ranging (LIDAR) topography acquired in 2008. Ambiguity because of channel shifting was avoided by referencing locations and analyses for the lowermost $18 \mathrm{~km}$ to a flood-plain kilometer (FPkm) centerline, measured from the river mouth along the centerline of the Holocene flood plain. In 2008, approximately $18 \mathrm{~km}$ of channel was within the 16-km length of flood plain comprising the study reach. Prominent landmarks and locations include the U.S. Highway 101 bridge at FPkm 0.9 (Rkm 1.4), Tide Rock at FPkm 4.2 (Rkm 4.9), North Fork Chetco River confluence at FPkm 7.6 (Rkm 8.3), and the USGS streamflow-gaging station (at Second Bridge) at FPkm 15.3 (Rkm 16.7).

Bed-material transport was calculated using sediment transport capacity relations of Parker (1990a,b) and Wilcock and Crowe (2003), which both provide transport capacity in terms of mass (in kilograms). This report presents bed-material transport in terms of mass (in metric tons, equivalent to $1,000 \mathrm{~kg}$ ). In the previous Chetco River bed-material transport study (Wallick and others, 2010), bedload flux was presented in terms of volume (in cubic meters) by converting from mass to volume using equation (1), which is approximately equivalent to applying a bulk density of 2.1 metric tons $/ \mathrm{m}^{3}$ :

$$
v=m /(1-n) \rho
$$

where $m$ is mass in kilograms, $v$ is volume in $\mathrm{m}^{3}, n$ is in situ porosity of bed-material sediment, and $\rho$ is particle density. In Wallick and others (2010), an in situ porosity of 0.21 was applied based on a range of porosity data collected by Milhouse (2001) as presented in Bunte and Abt (2001). A standard particle density of 2,650 kg/m $\mathrm{m}^{3}$ was applied. 


\section{Chetco River Study Area}

Refer to Wallick and others (2010) for description of Chetco River Basin and study area.

\section{Approach and Key Findings}

For this study, we followed the approach developed by Wallick and others (2010) to calculate daily bed-material flux using established sediment-transport relations at the Chetco River USGS streamflow gaging station at FPkm 15.3 (14400000). A complete description of the equations and their application to the Chetco River are provided in Wallick and others (2010) and summarized here.

\section{Estimation of Bed-Material Transport Rates Using Established Transport Equations}

Application of bed-material transport formulas is a common means of estimating sediment fluxes in streams (Collins and Dunne, 1989; Gomez, 1991; Hicks and Gomez, 2003). The basic premise of this approach is that for a site where hydraulic geometry and bed-material characteristics are known, transport capacity can be estimated as a function of discharge. Sediment-transport capacity is defined as the "maximum load a river can carry" (Gilbert and Murphy, 1914, pg. 35). For gravel-rich, transport-limited streams such as the Chetco River, transport capacity can be used to approximate bedload flux, so long as a valid transport relation is applied and an accurate description of channel hydraulics and bed material are used as inputs to the formula.

On the basis of multiple, independent analyses, Wallick and others (2010) determined that transport capacity estimates as computed using the Parker and Wilcock-Crowe equations provided a reasonable approximation of bedmaterial flux. Both of these equations have a similar theoretical framework and use grainsize data from the bar surface. The major distinction between the two approaches is in determination of the reference Shields shear stress $\left(\tau_{r s g}^{*}\right)$; in the Parker equation, $\tau_{r s g}^{*}$ is assumed to be the constant value 0.0386 , but in the WilcockCrowe equation, $\tau_{r s g}^{*}$ varies with the sand content of the surface bed material.

\section{Calculation of Bed-Material Flux}

In the previous Chetco River bed-material transport study, Wallick and others (2010) implemented the transport capacity relations using the software package Bedload Assessment in Gravel-bedded Streams (BAGS), (Pitlick and others, 2009). Within BAGS, users specify a transport equation, then provide cross section geometry, flow, and sediment parameters. The program then calculates the bed-material transport rate for a particular cross-section, at the specified flow. Repeating this process for multiple flows produces a relation between discharge $(Q)$ and bed-material transport rate $\left(Q_{s}\right)$, producing a site-specific sedimentdischarge rating curve. For the Chetco River, the data underlying the calculated $Q-Q s$ curves includes bed-material size data (collected at each of the analysis sites in 2008) and channel hydraulics, which were characterized with a validated HEC-RAS model constructed using 2008 LiDAR topography and 2008 bathymetric survey data (see Wallick and others [2010] for complete model description).

The $Q-Q$ r relations serve as a basis for calculating annual sediment transport fluxes. Typically, annual transport volumes are calculated using mean daily values (for example, Collins and Dunne [1989]), but because of the combination of the highly nonlinear transport rates and the rapid flow changes on the Chetco River during transport events, annual bed-material transport volumes determined from mean daily values are likely to underestimate true values. Therefore, Wallick and others (2010) based annual bed-material transport volumes on higher resolution unit- 
discharge values (recorded every 30 minutes before 2006 and every 15 minutes after 2006). However, substantial gaps in the unit-discharge data precluded a full accounting of sediment flux, so regression formulas were developed between daily transport volumes calculated from the unit-flow measurements and mean daily flow for all days of predicted transport (Wallick and others, 2010).

In the previous Chetco River study (Wallick and others, 2010), this process was repeated for multiple cross-sections throughout the study area, but in this study bed-material flux was calculated solely at the USGS streamflow gaging station at FPkm 15.3 (14400000) using the regression formula developed for that site by Wallick and others (2010). The regression formula was applied to daily mean flow data from the period October 1 , 2009, to March 30, 2011.

Although daily mean flow for the Chetco River gaging station is computed automatically on a daily basis, these data are considered provisional (subject to revision) until the data are formally reviewed and approved, which occurs on an ongoing basis. At the time this report was prepared, daily mean flow data were approved through December 28, 2010, so calculations for the period December 29, 2010, to March 31, 2011, used provisional data and may be subject to change once the final, approved flow record is available.

\section{Results of Calculated Bed-Material Flux}

The calculated bed-material flux for WY 2009 was 87,300 metric tons, as calculated by the Parker equation or 116,900 metric tons, as calculated by the Wilcock-Crowe equation (fig. 3 , table 1). Calculated bed-material flux in WY 2010 was substantially lower: 56,800 metric tons or 96,700 metric tons as calculated by the Parker and Wilcock-Crowe equations, respectively (fig. 3 , table 1 ).
Annual flux estimates for the period beginning April 1 and extending through March 31 were 84,700 metric tons in 2008-09, 45,500 metric tons in 2009-10 and 67,100 metric tons in $2010-11$, as calculated by the Parker equation. For the same periods, the WilcockCrowe equation provides slightly higher annual flux values: 111,700 metric tons 2008-09, 79,100 metric tons $2009-10$, and 134,300 metric tons in 2010-2011.

Temporal variation in bed-material transport reflects the timing and magnitude of peak flows, with most of the annual transport occurring during short periods of high discharge. For example, 61 percent of the WY 2009 transport occurred over 2 days, December 28-29, 2008, when peak flows exceeded the 5year recurrence-interval discharge of $1,425 \mathrm{~m}^{3} / \mathrm{s}$ (fig. 3, table 1). Although the mean annual flow for WY 2010 was greater than that for WY 2009, peak flows in WY 2010 were slightly less than the 2-year recurrence interval discharge of $1,060 \mathrm{~m}^{3} / \mathrm{s}$, resulting in much lower annual transport in WY 2010. The corresponding bedmaterial transport for the WY 2010 peak flow (occurring on January 1, 2010; fig. 3) was 16,800 metric tons, equivalent to 30 percent of the total WY 2010 bed-material transport

In terms of long-term trends in bed-material transport, the calculated flux values for WY 2009-10 were less than the average annual bedmaterial transport for the period 1970-2010: 105,300 or 152,300 metric tons for the Parker and Wilcock-Crowe equations, respectively. Overall, between 1970 and 2010, bed-material flux exceeded 200,000 metric tons in 7 years, (as calculated with the Parker equation), including two particularly high transport years (WY 1982 and WY 1997), which both encompassed wet winters and large flood events (table 1, fig. 4). During several exceptionally dry years, including WY 2001 and WY 1977 transport (as calculated with the Parker equation) was less than 3,000 metric tons. 

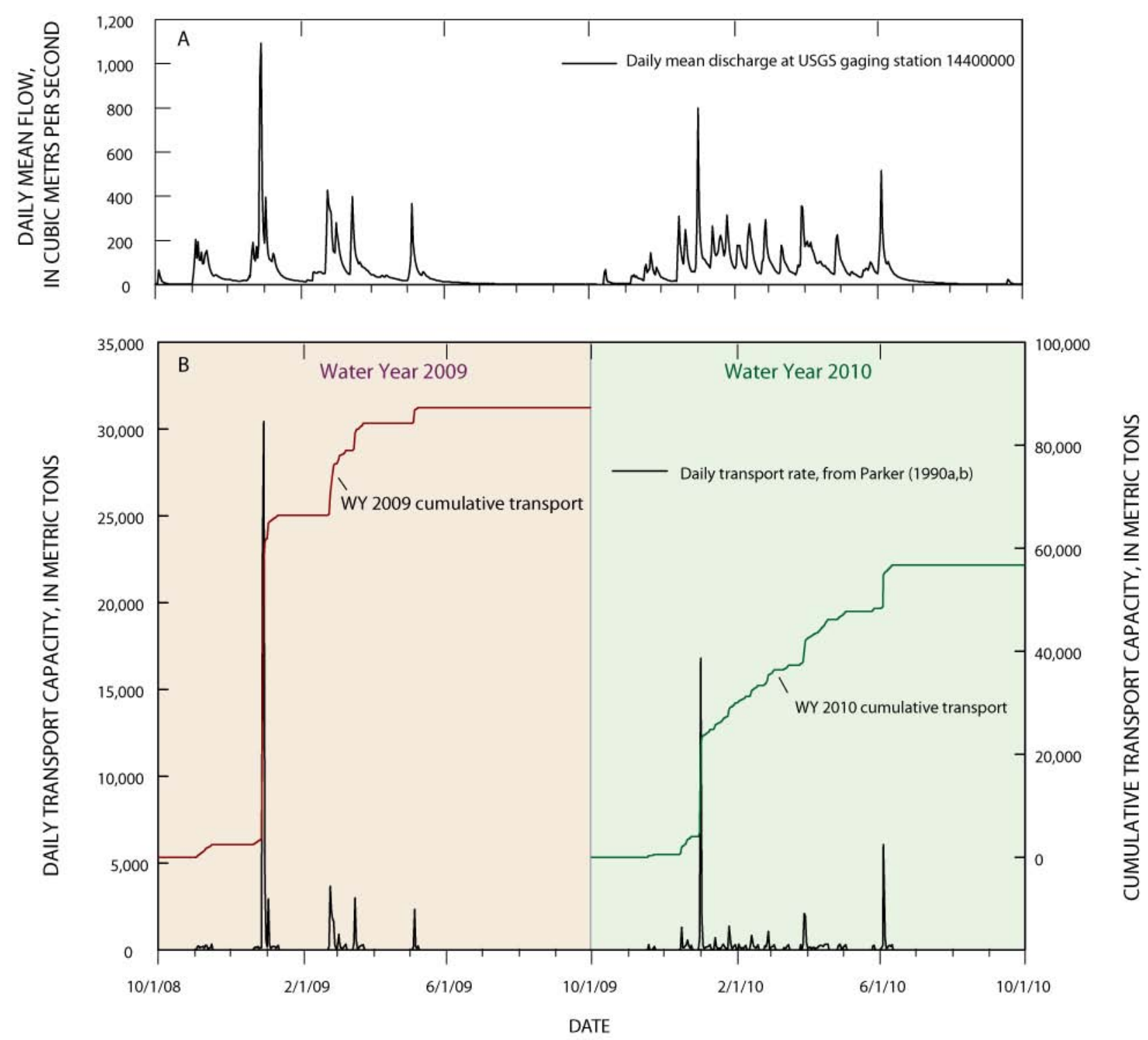

Figure 3. Graphs showing discharge and calculated bed-material transport capacity for water years 2009-2010 at the USGS streamflow gaging station at flood plain-kilometer 15.3 (144000000), Chetco River, Oregon: A. Daily mean discharge. B. Daily transport capacity and cumulative transport capacity, as calculated using the Parker $(1990 a, b)$ transport equation. 

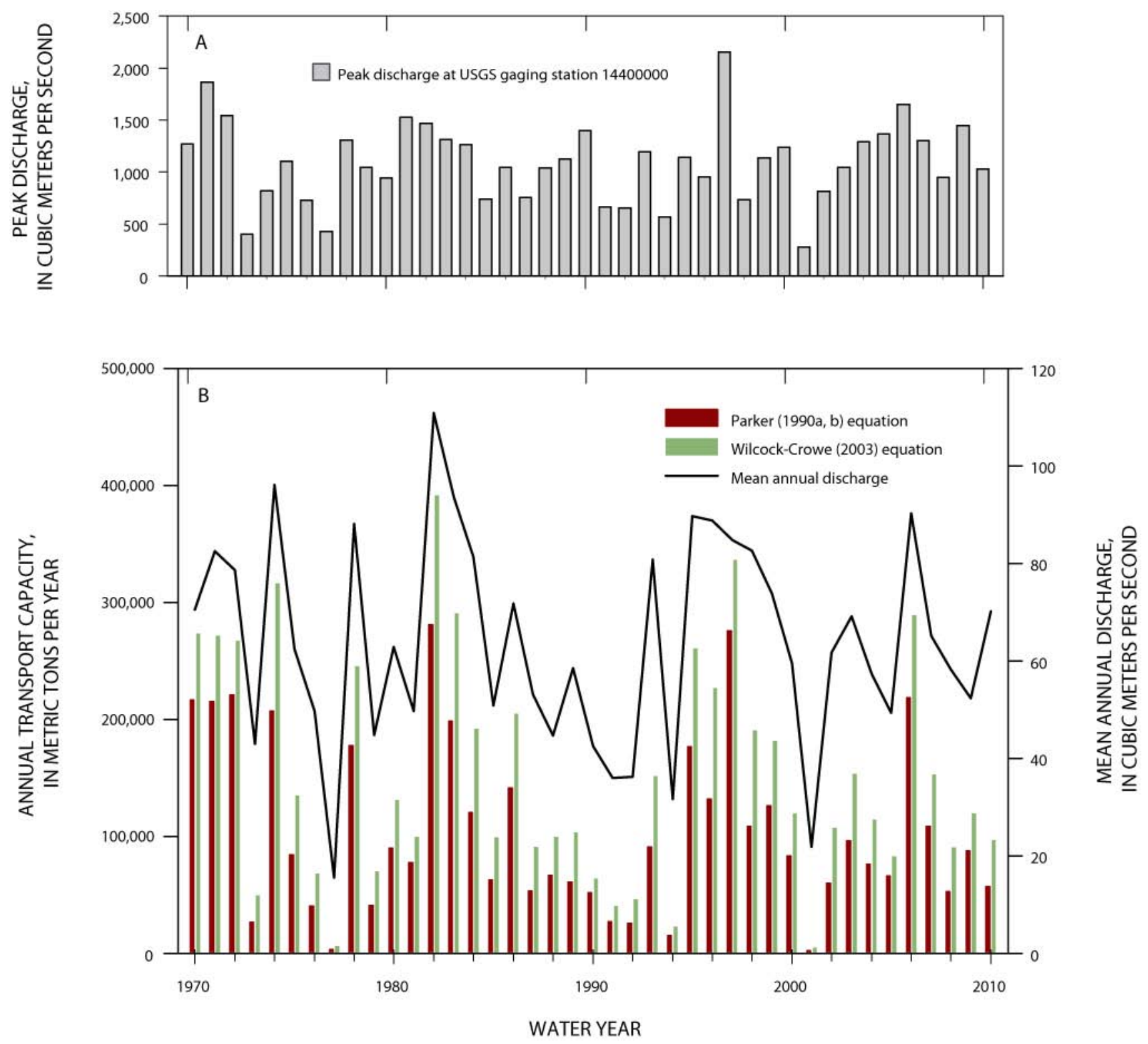

Figure 4. Graphs showing peak discharge, annual transport capacity, and mean annual discharge for water years 1970-2010 at the USGS streamflow gaging station at flood plain kilometer 15.3 (14400000), Chetco River Oregon: A. Peak discharge. B. Annual transport capacity, as calculated on the basis of the Parker $(1990 \mathrm{a}, \mathrm{b})$ and Wilcock and Crowe (2003) transport equations. 
Table 1. Summary of calculated transport capacity, peak flow, and mean annual flow in the Chetco River, Oregon for water years 1970-2010

[Transport capacity values for 1970-2008 from Wallick and others, (2010);

Abbreviations: $\mathrm{m}^{3} / \mathrm{sec}$, cubic meters per second]

\begin{tabular}{|c|c|c|c|c|}
\hline Water year & $\begin{array}{l}\text { Transport, using } \\
\text { Parker equation } \\
\text { (metric tons) }\end{array}$ & $\begin{array}{l}\text { Transport, using } \\
\text { Wilcock-Crowe } \\
\text { equation } \\
\text { (metric tons) }\end{array}$ & $\begin{array}{c}\text { Peak } \\
\text { discharge } \\
\left.\text { ( } \mathrm{m}^{3} / \mathrm{sec}\right)\end{array}$ & $\begin{array}{c}\text { Mean annual } \\
\text { discharge } \\
\text { (m3/sec) }\end{array}$ \\
\hline 1970 & 216,700 & 273,400 & 1,269 & 70.5 \\
\hline 1971 & 215,100 & 271,200 & 1,863 & 82.4 \\
\hline 1972 & 220,900 & 266,800 & 1,543 & 78.6 \\
\hline 1973 & 26,600 & 49,200 & 399 & 42.9 \\
\hline 1974 & 206,800 & 316,100 & 821 & 96.1 \\
\hline 1975 & 83,900 & 134,500 & 1,102 & 62.3 \\
\hline 1976 & 40,200 & 68,100 & 728 & 49.6 \\
\hline 1977 & 2,900 & 5,900 & 430 & 15.6 \\
\hline 1978 & 177,200 & 245,000 & 1,306 & 88.1 \\
\hline 1979 & 40,600 & 70,000 & 1,045 & 44.8 \\
\hline 1980 & 89,800 & 130,900 & 943 & 62.8 \\
\hline 1981 & 77,600 & 99,500 & 1,524 & 49.6 \\
\hline 1982 & 280,800 & 391,400 & 1,467 & 110.8 \\
\hline 1983 & 198,400 & 290,400 & 1,311 & 93.6 \\
\hline 1984 & 120,300 & 191,900 & 1,263 & 81.3 \\
\hline 1985 & 62,700 & 99,000 & 742 & 50.8 \\
\hline 1986 & 141,100 & 204,300 & 1,045 & 71.8 \\
\hline 1987 & 53,000 & 90,600 & 753 & 53.1 \\
\hline 1988 & 66,700 & 99,200 & 1,037 & 44.6 \\
\hline 1989 & 60,800 & 102,900 & 1,127 & 58.5 \\
\hline 1990 & 51,500 & 63,800 & 1,396 & 42.5 \\
\hline 1991 & 26,800 & 40,400 & 663 & 35.9 \\
\hline 1992 & 25,600 & 46,100 & 651 & 36.2 \\
\hline
\end{tabular}


Table 1. Summary of calculated transport capacity, peak flow, and mean annual flow in the Chetco River, Oregon for water years 1970-2010—continued

[Transport capacity values for 1970-2008 from Wallick and others, (2010); Abbreviations: $\mathrm{m}^{3} / \mathrm{sec}$, cubic meters per second]

\begin{tabular}{|c|c|c|c|c|}
\hline Water year & $\begin{array}{l}\text { Transport, using } \\
\text { Parker equation } \\
\text { (metric tons) }\end{array}$ & $\begin{array}{l}\text { Transport, using } \\
\text { Wilcock-Crowe } \\
\text { equation } \\
\text { (metric tons) }\end{array}$ & $\begin{array}{c}\text { Peak } \\
\text { discharge } \\
\text { (m³/sec) }\end{array}$ & $\begin{array}{l}\text { Mean annual } \\
\text { discharge } \\
\left(\mathrm{m}^{3} / \mathrm{sec}\right)\end{array}$ \\
\hline 1993 & 90,800 & 151,200 & 1,192 & 80.8 \\
\hline 1994 & 15,100 & 22,500 & 566 & 31.6 \\
\hline 1995 & 176,500 & 260,300 & 1,138 & 89.7 \\
\hline 1996 & 131,900 & 226,400 & 952 & 88.7 \\
\hline 1997 & 275,400 & 335,900 & 2,155 & 84.8 \\
\hline 1998 & 108,400 & 190,200 & 734 & 82.6 \\
\hline 1999 & 126,000 & 181,100 & 1,133 & 73.7 \\
\hline 2000 & 83,000 & 119,500 & 1,238 & 59.5 \\
\hline 2001 & 2,200 & 4,400 & 279 & 21.8 \\
\hline 2002 & 59,900 & 107,100 & 816 & 61.6 \\
\hline 2003 & 95,800 & 152,900 & 1,042 & 69.1 \\
\hline 2004 & 76,100 & 113,900 & 1,289 & 57.3 \\
\hline 2005 & 65,800 & 82,700 & 1,365 & 49.3 \\
\hline 2006 & 218,500 & 288,600 & 1,651 & 90.2 \\
\hline 2007 & 108,200 & 152,600 & 1,300 & 65.1 \\
\hline 2008 & 52,600 & 90,300 & 949 & 58.2 \\
\hline 2009 & 87,300 & 116,900 & 1,447 & 52.3 \\
\hline 2010 & 56,800 & 96,700 & 1,025 & 70.2 \\
\hline
\end{tabular}




\section{References Cited}

Bunte, Kristin., and Abt, S.R., 2001, Sampling surface and subsurface particle-size distributions in wadable gravel and cobble-bed streams for analyses in sediment transport, hydraulics, and streambed monitoring: U.S. Department of Agriculture, Forest Service, Rocky Mountain Research Station, General Technical Report RMRS-GTR-74, 428 p.

Collins, B.D., and Dunne, Thomas, 1989, Gravel transport, gravel harvesting, and channel-bed degradation in rivers draining the southern Olympic Mountains, Washington, U.S.A.: Environmental Geology, v. 13, no. 3, p. 213-224.

Gilbert, G.K., and Murphy, E.C., 1914, The transportation of debris by running water: U.S. Geological Survey Professional Paper 86, p. 263.

Gomez, Basil, 1991, Bedload transport: Earth-Science Reviews, v. 31, no. 2, p. 89-132.

Hicks, D.M., and Gomez, Basil, 2003, Sediment transport, in Kondolf, G. M. and Piegay, H., eds., Tools in fluvial geomorphology: Chichester, John Wiley and Sons, p. 425-461.

Kondolf, G.M., 1994, Geomorphic and environmental effects of instream gravel mining: Landscape and Urban Planning, v. 28, no. 2-3, p. 225-243.

Kondolf, G.M., 1997, Hungry water-Effects of dams and gravel mining on river channels: Environmental Management, v. 21, no. 4, p. 533-551.

Milhous, R.T., 2001, Specific weight and median size of the bed material of gravel and cobble bed rivers, in Proceedings of the Seventh Federal Interagency Sedimentation Conference, March 25-29, 2001, Reno, Nevada: U.S. Geological Survey, p. III-70-77 , http://pubs.usgs.gov/misc/FISC_19472006/pdf/1st-7thFISCs-CD/7thFISC/7Fisc-V1/7FISC1-3.pdf.

Parker, Gary, 1990a, Surface-based bedload transport relation for gravel rivers: Journal of Hydraulic Research, v. 28, no. 4, p. 417-436.

Parker, Gary, 1990b, The ACRONYM series of PASCAL programs for computing bedload transport in gravel rivers: St. Anthony Falls Laboratory, University of Minnesota, External Memorandum M220, $124 \mathrm{p}$.

Pitlick, John., Cui, Y.T., and Wilcock, P.R., 2009, Manual for computing bed Load transport using BAGS (bedload assessment for gravel-bed streams) Software: Fort Collins, Colorado, U.S. Department of Agriculture, Forest Service, Rocky Mountain Research Station, General Technical Report RMRS-GTR-223, 45 p.

Wallick, J.R., Anderson, S.W., Cannon, C., and O’Connor, J.E., 2010, Channel change and bedmaterial transport in the lower Chetco River, Oregon: U.S. Geological Survey Scientific Investigations Report 2010-5065, 68 p.

Wilcock, P.R., and Crowe, J.C., 2003, Surface-based transport model for mixed-size sediment: Journal of Hydraulic Engineering, v. 129, p. 120-128. 
